\title{
Mer simulering!
}

\begin{abstract}
Den obligatoriske kurspakken for leger i spesialisering i anestesiologi ble nylig revidert. Vi er arrangører for et av kursene, grunnkurs 2, hvor simulering og ferdighetstrening er sentrale pedagogiske virkemidler noe som gir deltakerne mulighet til å trene ikke-tekniske ferdigheter. Det er et kostbart og ressurskrevende kurs å arrangere, men vi mener gevinsten i form av økt læringsutbytte og inspirerte kursdeltakere langt overskygger de investerte midlene. Vi håper våre erfaringer kan motivere til økt bruk av ferdighetstrening og simulering i videre- og etterutdanningen i alle spesialiteter.
\end{abstract}

Engelsk oversettelse av hele artikkelen på www.tidsskriftet.no

\author{
Håkon Bjorheim Abrahamsen \\ Forskning og utvikling \\ Stiftelsen Norsk Luftambulanse \\ og \\ Akuttklinikken \\ Stavanger universitetssjukehus \\ Katrine Finsnes \\ k.finsnes@gmail.com \\ Akuttklinikken \\ Stavanger universitetssjukehus
}

Simulatorer ble introdusert som et pedagogisk verktøy innen luftfart så tidlig som i begynnelsen av 1920-årene. Hensikten var å standardisere trening på risikofylte prosedyrer samt redusere kostnader og risiko for piloter og passasjerer.

Først i 1960 ble den første medisinske pasientsimulatoren introdusert på markedet (1). Den ble kalt Resusci Anne og ble til gjennom et pionerarbeid initiert av et samarbeid mellom Asmund Laerdal og Peter Safar. Resusci Anne var en enkel dukke som var konstruert med tanke på trening av basal hjerte- og lungeredning.

Medisinske simulatorer har siden antatt en rekke ulike former. Det finnes alt fra enkle modeller for trening på innleggelse av venekanyle til skjermbaserte dataprogrammer og sofistikerte menneskeliknende dukker. De mest avanserte dukkene finnes i naturtro størrelse og kan programmeres eller fjernstyres til å mimikere patologiske forhold og respondere på ulike former for intervensjon.

De siste 15 årene har vi sett en eksplosiv tilvekst av sentre som er spesielt tilrettelagt for medisinsk simulering. Stavanger Acute medicine Foundation for Education and Research (SAFER) er et slikt simuleringssenter som ble åpnet i Stavanger i 2006.

\section{Ikke-tekniske ferdigheter}

Simulering som metode gir helsepersonell en unik mulighet til å trene praktiske ferdig- heter og tekniske prosedyrer samt øve på klinisk diagnostikk og behandling. Gode tekniske og kliniske ferdigheter er imidlertid ikke tilstrekkelig for optimal trygg og sikker pasientbehandling. Forskning har nemlig vist at menneskelig svikt relatert til mangelfulle ikke-tekniske ferdigheter er medvirkende årsak i inntil $80 \%$ av uønskede hendelser $i$ anestesi og intensivmedisin (2). Ikke-tekniske ferdigheter kan defineres som «kognitive, sosiale og personlige ferdigheter som komplementerer tekniske ferdigheter og som bidrar til sikker og effektiv pasientbehandling» (3). Eksempler på sentrale ikke-tekniske ferdigheter er situasjonsbevissthet, beslutningstaking, kommunikasjon, teamarbeid og ledelse. Simulering egner seg spesielt godt til å trene ikke-tekniske ferdigheter (3).

I spesialistutdanningen i Norge er man lite opptatt av trening og evaluering av legers ikke-tekniske ferdigheter.

\section{Revisjon av kurspakken}

Anestesileger har til alle tider vært engasjert $\mathrm{i}$ å bedre pasientsikkerheten (4). Spesialitetskomiteen $\mathrm{i}$ anestesiologi initierte høsten 2006 arbeidet med revisjon av den obligatoriske kurspakken for leger i spesialisering $i$ anestesiologi (5). Intensjonen med revisjonen var i første omgang å bedre læringsutbyttet for kursdeltakerne ved å innføre utstrakt bruk av smågruppeundervisning, ferdighetstrening og simulering. I tillegg var det en målsetting å bedre pasientsikkerheten, utnytte investerte midler på en mer hensiktsmessig måte og samtidig redusere de totale kursutgiftene (5). For å nå denne ambisiøse målsettingen ble det en forutsetning at kursdeltakerne måtte forberede seg grundigere enn tidligere i forkant av kursene for å skape en felles kunnskapsplattform, da det ikke ville bli avsatt tid til rene litteraturstudier i løpet av kurset.

For å effektivisere forstudiene ble det lagt opp til utstrakt bruk av såkalt e-læring.
Hvert enkelt kurs har fått en dedikert hjemmeside der deltakerne har tilgang til praktisk informasjon om kurset, linker til anbefalt litteratur, oppgaver og instruksjonsvideoer. E-læring åpner også for enkel kommunikasjon deltakerne imellom og mellom kursdeltakere og emneansvarlige.

Som et ledd i kvalitetsforbedringsarbeidet har spesialitetskomiteen i anestesiologi tatt initiativ til å bygge opp en felles Internettportal for samtlige kurs i den obligatoriske kurspakken. Man har intensjoner om at portalen skal kunne forenkle diverse administrative oppgaver og på sikt også gjøres tilgjengelig for samtlige spesialiteters kurspakker.

\section{Grunnkurs 2}

Den nye kurspakken i anestesiologi består av totalt sju kurs som bygger på hverandre. De to første er grunnleggende kurs som skal gi en innføring i anestesifaget og gjøre kursdeltakerne kompetente til å gå selvstendige vakter. Grunnkurs 2 (GK 2) arrangeres som det andre i rekken med maksimalt 30 deltakere hver gang. Det er Akuttklinikken ved Stavanger universitetessjukehus som har fått ansvaret for å arrangere dette fem dager lange kurset. GK 2 ble første gang arrangert våren 2009 og er siden holdt to ganger årlig.

Kurset skal gi grunnleggende prinsipper for, kunnskaper om og praktiske ferdigheter $i$ håndtering $\mathrm{av}$ vitale funksjoner hos kritisk syke og skadede pasienter. Utvalgte problemstillinger som kjennetegner anestesiologisk vaktarbeid på sykehus belyses gjennom 16 simuleringer, 13 ferdighetsstasjoner og noe arbeid i smågrupper.

Temaene på simuleringsstasjonene er en blanding av temaer som tradisjonelt har vært hyppig benyttet i simuleringssammenheng, som hjertestans og algoritmer for håndtering av vanskelig luftvei, og temaer som umiddelbart ikke synes å ligge til rette for simulering, som eksaserbasjon av kols, sepsis og vurdering av behandlingsavgrensning. 


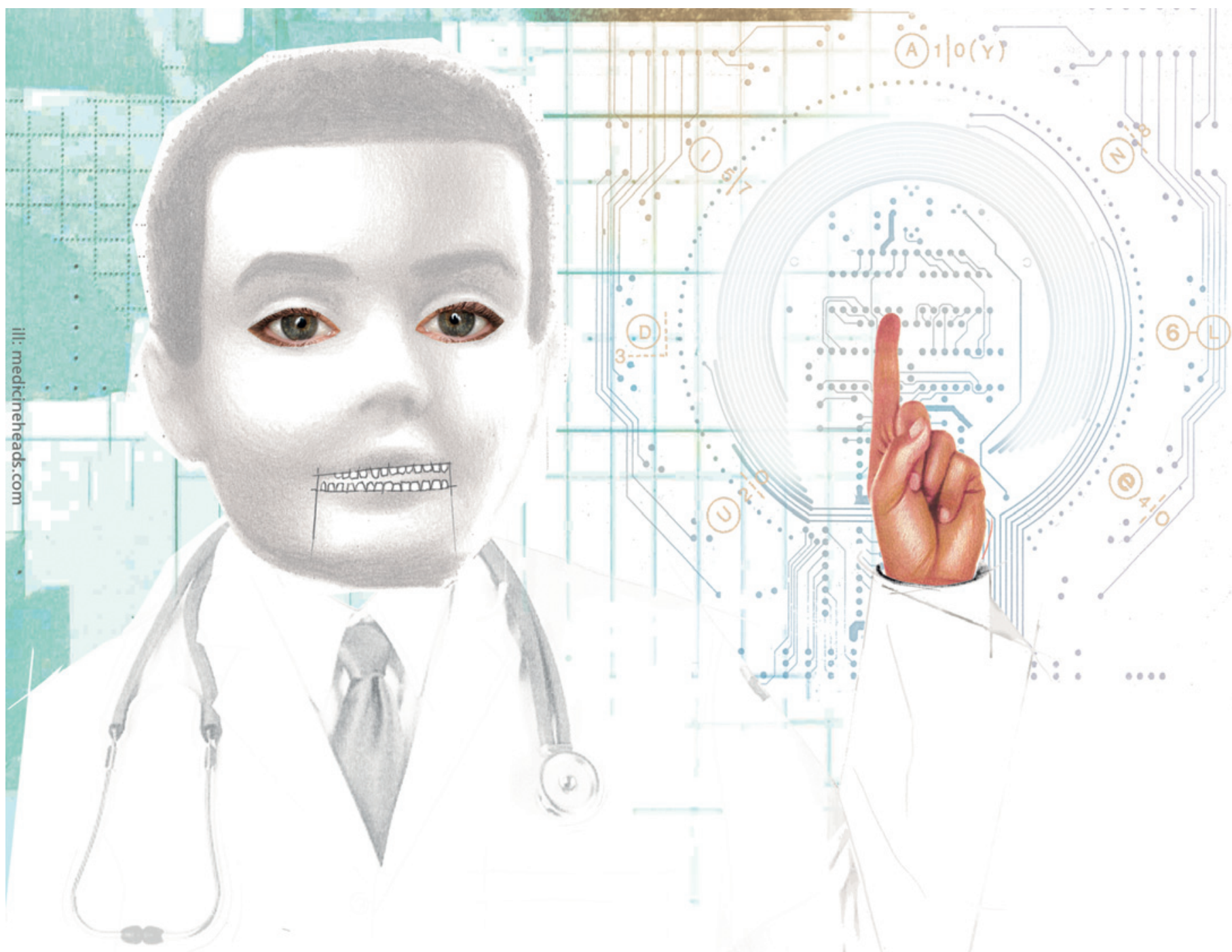

Illustrasjon Trond Nordahl/Medicineheads

På ferdighetsstasjonene får deltakerne anledning til å trene innleggelse av thoraxdren på griseribbe, nødtrakeotomi på lammestrupe, intraossøs tilgang på kyllingbein og plastmodeller, samt mulighet til å øve på innleggelse av navlevenekateter på human navlestreng.

Tradisjonelle forelesninger er så godt som fjernet fra kursprogrammet med unntak av mer interaktive presentasjoner av noen temaer som egner seg bedre for diskusjon enn simulering, som for eksempel melderutiner ved uønskede hendelser.

De fleste undervisere har formell opplæring i form av kurset Train-The-Trainer (TTT). Dette er et tre-dagers kurs med teori om pedagogikk for voksne, strategier for læring, kommunikasjon og supervisert trening i å drive simuleringsscenarier. TTTkurset er basert på et tilsvarende dansk kurs meds den målsetting å utvikle evnen til å stimulere kursdeltakernes egenrefleksjon og til å gi konstruktive tilbakemeldinger. Dette skaper et trygt læringsmiljø som er en forutsetning for å lede eller fasilitere smågruppeundervisning og simulering.
Alle disse faktorene er med på å skape et trygt læringsmiljø.

\section{Erfaringer}

Simulering og ferdighetstrening er læringsformer som forutsetter engasjement og en betydelig mer aktiv deltakelse fra kursdeltakerne enn det som tradisjonelt har vært vanlig på forelesningsbaserte kurs. Dette kan av mange oppleves som uvant og utfordrende i starten. I tillegg er vår erfaring at nettopp leger er skeptiske til å eksponere seg faglig og personlig for kolleger og kursarrangører. Vi har derfor forsøkt å bygge opp kurset på en pedagogisk måte der deltakerne får en gradvis innføring $i$ hva simulering og ferdighetstrening er og hva som forventes av den enkelte. Hensikten med dette er å etablere en trygghet rundt konseptet og en tillit til at den enkeltes prestasjoner på simuleringsrommene ikke blir samtaleemne i påfølgende kaffepauser.

For å kunne evaluere og kontinuerlig forbedre kurset har vi utarbeidet et detaljert evalueringsskjema for hver av kursdagene. Samtlige simuleringer, ferdighetsstasjoner, interaktive forelesninger og totalinntrykket av hele kurset gis poeng på en tipunkts Likert-skala med rom for utfyllende kommentarer. Det er en forutsetning at skjemaene fylles ut anonymt og fortløpende for å øke validiteten.

I etterkant av hvert kurs har kurskomiteen systematisk analysert og sammenfattet informasjon som har fremkommet i evalueringsskjemaene. Basert på tilbakemeldingene har vi aktivt forsøkt å forbedre kurset både med henhenblikk på faglig innhold, pedagogiske virkemidler, logistikk og det sosiale programmet.

De første kursene som ble arrangert, omfattet f.eks. opplæring i både basal hjerte--lunge-redning ved hjelp av livredningsdukken MiniAnne og $i$ avansert hjerte--lungeredning (A-HLR). Dette ble av de fleste deltakerne oppfattet som elementær kunnskap med begrenset faglig utbytte, og mange hadde allerede erfaring fra organisert trening i både basal og avansert hjerte-lunge-redning på sine respektive avdelinger. Vi valgte derfor å fjerne den basale HLR-treningen fra kursprogrammet. 
Trening i A-HLR har vi beholdt, men oppmerksomheten er rettet mot diagnostikk og behandling av mer spesielle årsaker til hjertestans som blant annet lungeemboli, drukning og intoksikasjon med lokalanestetika. I tillegg får deltakerne mulighet til å praktisere A-HLR med tillegg av forstyrrende elementer som bl.a. støy og emosjonelt ustabile tilskuere, som er en relativt vanlig situasjon prehospitalt. I etterkant av simuleringen diskuteres potensielle effekter av såkalt sosioemosjonelt stress på kvaliteten av resuscitering (6). Alle scenarioene skal være realistiske og er basert på fasilitatorenes egne kliniske erfaringer.

GK 2 er et omfattende og intenst kurs både for fasilitatorer og ikke minst for kursdeltakerne. Spesielt er logistikken krevende på grunn av en rekke samtidige simuleringer og ferdighetsstasjoner. Hver kursdag er en mengde personer engasjert som fasilitatorer og operatører, og flere av stasjonene krever mye forberedelse og utstyr. I tillegg til at det frigis flere leger fra vår egen anestesiavdeling i Stavanger, er det også etablert samarbeid med andre sykehus, både for å øke den faglige kvaliteten og for å avhjelpe personellsituasjonen lokalt. Alle disse faktorene gjør som tidligere nevnt GK 2 til et relativt kostbart kurs å arrangere, men vi mener likevel gevinstene i form av økt læringsutbytte langt overskygger de investerte midlene.

\section{Konklusjon}

Vår erfaring som arrangører av GK 2 i Stavanger er at medisinsk simulering i kombinasjon med ferdighetstrening og smågruppeundervisning er velegnede og effektive pedagogiske verktøy som både engasjerer og stimulerer til videre læring. Simulering muliggjør realistisk trening på alt fra enkle hverdagslige problemstillinger til avanserte risikofylte prosedyrer som man sjelden benytter. Treningen kan foregå innenfor trygge rammer, uten at pasienter utsettes for fare.

I tillegg får akuttmedisinske team anledning til å trene sammen og gis sjansen til å øve sentrale ikke-tekniske ferdigheter som det foreløpig ikke finnes noe etablert system for innenfor spesialistutdanningen i Norge. Verktøy for evaluering av slike ferdigheter finnes nå tilgjengelig for både kirurger, operasjonssykepleiere og anestesileger (3), og flere er under utvikling. Denne type verktøy åpner muligheten for at man kan etablere standardiserte krav til både tekniske og ikke-tekniske ferdigheter hos leger. Simulering er en metode for å trene disse ferdighetene.

Helsinkideklarasjonen for pasientsikkerhet $\mathrm{i}$ anestesiologi oppfordrer til økt fokus på pasientsikkerhet (4). Et viktig skritt på veien vil være å sørge for at leger i spesialisering får en solid grunnutdanning og sunne holdninger til pasientsikkerhet.

Basert på våre erfaringer mener vi trygt å kunne anbefale et liknende kurskonsept som grunnkurs 2 også innenfor andre medisinske spesialiteter.

\section{Håkon Bjorheim Abrahamsen (f. 1975)}

arbeider som lege i spesialisering ved Anestesiavdelingen, Stavanger universitetssjukehus og er doktorgradsstipendiat i Stiftelsen Norsk Luftambulanse. Forskningsprosjektet hans utgår fra Institutt for samfunnsmedisinske fag, Universitetet i Bergen og omhandler menneskelige faktorer og ikke-tekniske ferdigheter i prehospitale tjenester med særlig fokus på luftambulansetjenesten i Norge. Han er tilknyttet Nasjonalt kompetansesenter for legevakt- medisin, Uni helse og Forskningsgruppe for akuttmedisin, Universitetet i Stavanger. Han har en solid tverrfaglig bakgrunn som ingeniør med spesialisering i medisinsk teknologi og kybernetikk.

Ingen oppgitte interessekonflikter.

\section{Katrine Finsnes (f. 1980)}

arbeider som lege i spesialisering ved Anestesiavdelingen, Stavanger universitetssjukehus, har også spesialisert seg i villmarksmedisin og er Fellow of the Academy of Wilderness Medicine gjennom the Wilderness Medical Society i USA. Hun er medlem i spesialitetskomiteen $i$ anestesiologi og skal nå reise ut og jobbe som anestesilege i Leger Uten Grenser. Ingen oppgitte interessekonflikter.

Litteratur

1. Grenvik A, Schaefer J. From Resusci-Anne to SimMan: the evolution of simulators in medicine. Crit Care Med 2004: 32 (suppl): S56-7.

2. Williamson JA, Webb RK, Sellen A et al. The Australian Incident Monitoring Study. Human failure: an analysis of 2000 incident reports. Anaesth Intensive Care 1993; 21: 678-83.

3. Flin R, Patey R, Glavin R et al. Anaesthetists' nontechnical skills. Br J Anaesth 2010; 105: 38-44.

4. Mellin-Olsen J, Staender S, Whitaker DK et al. The Helsinki Declaration on Patient Safety in Anaesthesiology. Eur J Anaesthesiol 2010; 27: 592-7.

5. Sterud B. Revidert obligatorisk kurspakke i anestesiologi - informasjon. NAForum 2008; 21 : 74-7. http://www.startsiden.no/sok/index.html?tr= lang_no\&q=Sterud \%20B.\%20Revidert $\% 20$ obligatorisk\%20kurspakke\%20i\%20anestesiologi $\% 20 \%$ E2\%80\%93\%20informasjon (13.10.2011).

6. Bjørshol CA, Myklebust H, Nilsen KL et al. Effect of socioemotional stress on the quality of cardiopulmonary resuscitation during advanced life support in a randomized manikin study. Crit Care Med 2011; 39: 300-4.

Mottatt 8.8. 2011 og godkjent 29.9. 2011. Medisinsk redaktør Siri Lunde. 